\title{
TORÇÃO UTERINA EM HAMSTER (Mesocricetus auratus) -RELATO DE CASO MÁRCIO CHIQUITO ${ }^{1}$; PAULO ROGÉRIO MANGINI'; PEDRO RIBAS WERNER ${ }^{2}$; GUILHERME GONÇALVES ${ }^{3}$; JOSÉ RICARDO PACHALY ${ }^{2}$
}

${ }^{1}$ Mestrandos do Curso de Pós-Graduação em Ciências Veterinárias da Universidade Federal do Paraná. ${ }^{2}$ Professores da Universidade Paranaense - UNIPAR, Umuarama-PR. ${ }^{3}$ Aluno do Curso de Graduação em Medicina Veterinária da Universidade Federal do Paraná.

Uma fêmea hamster, de nove meses de idade, aos 10 dias de gestação, apresentou manifestações semelhantes à cólica, entrou em choque e morreu. $\mathrm{O}$ abdome se apresentava mais severamente dilatado à esquerda. À necropsia, foram encontrados fígado em noz moscada e estrias radiais pálidas no córtex renal. Encontrou-se uma torção uterina de 180 graus em sentido horário. O útero continha seis fetos. Os vasos da parede uterina apresentavam-se fortemente ingurgitados. As lesões renais e hepáticas encontradas foram consideradas compatíveis com o quadro de choque. A literatura consultada não cita nenhum caso semelhante em hamster. Nos animais domésticos de grande porte, as torções uterinas são mais comuns no terço final da gestação ou no puerpério, podendo ser causadas por mudanças bruscas de posição do animal. 